\title{
Perspective: cardiovascular disease and the Covid-19 pandemic
}

\author{
Tommaso Gori ${ }^{1}$. Jos Lelieveld ${ }^{2}$. Thomas Münzel ${ }^{1}$
}

Received: 30 March 2020 / Accepted: 6 April 2020 / Published online: 10 April 2020

(c) Springer-Verlag GmbH Germany, part of Springer Nature 2020

\begin{abstract}
We summarize the cardiovascular risks associated with Covid-19 pandemic, discussing the risks for both infected and noninfected patients.
\end{abstract}

Keywords Covid-19 $\cdot$ Cardiovascular disease $\cdot$ Pollution

\section{Introduction}

Cardiovascular disease patients are at particularly high risk for mortality from Covid-19 due to their frailty and susceptibility for a myocardial involvement [1]. Sars-Cov-2 effects on microvascular function, notably pericyte injury and particularly in patients with heart failure, have also been reported [2]. In addition, drugs used to treat Covid19 patients have cardiovascular side effects (Table 1), the burden of which will unfortunately need to be evaluated in retrospect. The toll of the current pandemic will, however, not be limited to those infected by the virus (Fig. 1). We here provide a perspective on two aspects not strictly related to Covid-19 as a disease: the multiple implications for cardiovascular care and the indirect ones related to impact on society and environment.

\section{The impact on the care of cardiovascular patients}

To reduce the spread of Sars-Cov- 2 and allocate resources to Covid-19 patients, up to $80 \%$ of the elective interventions were indefinitely postponed, first in Italy and then in most countries, with "unknown effects on patient prognosis" [3]. Nurses and physicians were also affected while trying to

Tommaso Gori

tommaso.gori@unimedizin-mainz.de

1 Department of Cardiology, Universitätsmedizin Mainz and DZHK Standort Rhein-Main, Langenbeckstrasse 1, 55131 Mainz, Germany

2 Max-Planck Institut für Chemie, Mainz, Germany help the diseased, and colleagues admitting their impotency against an unprecedented challenge deserve all our solidarity and respect. Most hospitals have suspended elective admissions and interventions, and a significant drop in the access to emergency departments (by $30 \%$ in Milan) and a decrease of up to $50 \%$ in the incidence of non-ST-elevation myocardial infarction cases has been reported [4], with a relative shift in the epidemiology of acute coronary syndrome patients towards more severe ST-elevation myocardial infarctions [5]. In the present contingency of "suspended life", there is a potential risk that the effects of previous successful awareness campaigns [6] designed to emphasize the importance of early presentation in case of chest pain are lost and that patients with chest pain avoid contacting medical services for fear of contagion or, even worse, have no possibility to access overcrowded emergency services. Reports in this regard have recently been published [7]. Furthermore, the new, emergency-driven changes to hospital logistics conflict with important principles of treatment of patients with acute coronary syndromes: patients with an undefined contact history or ambiguous symptoms are often approached as potential Sars-Cov-2 positive at the time of their medical contact. As a result, the symptom-toballoon intervals are prolonged to perform the necessary screenings, resulting in a systematic delay of treatment. In some countries, the number of hospitals providing primary percutaneous coronary intervention had to be reduced to allocate resources to the treatment of Covid-19 patients [5], and in several centers, the standard protocols for ruling out acute coronary syndrome cases with two troponin measurements could not be respected. The opposite may also tragically occur: given the overlap of major symptoms (dyspnea, cough, elevated heart rate, low blood pressure), patients with 
Table 1 Incidence of cardiovascular side effects of potential drug therapies for Covid-19 (only those with incidence $>0.01 \%$ are quoted)

Fig. 1 Direct and indirect implications of Covid-19 for cardiovascular care

\begin{tabular}{|c|c|c|}
\hline Drug & Possible cardiovascular side effect & Incidence \\
\hline Ribavirin & $\begin{array}{l}\text { - Anemia } \\
\text { - Tachycardia } \\
\text { - Myocardial infarction } \\
\text { - Cardiomyopathy, arrhythmia } \\
\text { - Hypo- or hypertension } \\
\text { - Vasculitis }\end{array}$ & $\begin{array}{l}>10 \% \\
1-10 \% \\
0.1-1 \% \\
<0.1 \% \\
1-10 \% \\
<0.1 \%\end{array}$ \\
\hline $\begin{array}{l}\text { Lopinavir/ } \\
\text { Ritonavir }\end{array}$ & $\begin{array}{l}\text { - Hypertension } \\
\text { - Deep vein thrombosis } \\
\text { - Ischemic events } \\
\text { - AV Block } \\
\text { - Increased concentration of amiodarone, drone- } \\
\text { darone }\end{array}$ & $\begin{array}{l}1-10 \% \\
0.1-1 \% \\
0.1-1 \% \\
0.1-1 \%\end{array}$ \\
\hline $\begin{array}{l}\text { Chloroquine/ } \\
\text { Hydroxychloroquine }\end{array}$ & $\begin{array}{l}\text { - Hypotension, ECG changes } \\
\text { - Cardiomyopathy } \\
\text { - QT prolongation } \\
\text { - Interaction with antiarrhythmics }\end{array}$ & $\begin{array}{l}0.1-1 \% \\
<0.1 \% \\
\text { Unknown }\end{array}$ \\
\hline Methylprednisolone & $\begin{array}{l}\text { - Fluid retention } \\
\text { - Electrolyte disturbances } \\
\text { - Hypertension } \\
\text { - Atherosclerosis }\end{array}$ & Not reported \\
\hline $\begin{array}{l}\text { Biologicals (Tocilizumab, eculizumab, } \\
\text { bevacizumab }^{\mathrm{a}} \text { ) }\end{array}$ & - Hypertension & $1-10 \%$ \\
\hline Immunosuppressive agents & $\begin{array}{l}\text { - Bradycardia, AV-block } \\
\text { - Hypertension }\end{array}$ & \\
\hline
\end{tabular}

${ }^{a}$ For bevacizumab the literature reports a risk of congestive heart failure, supraventricular tachycardia, hypertension, thromboembolic events

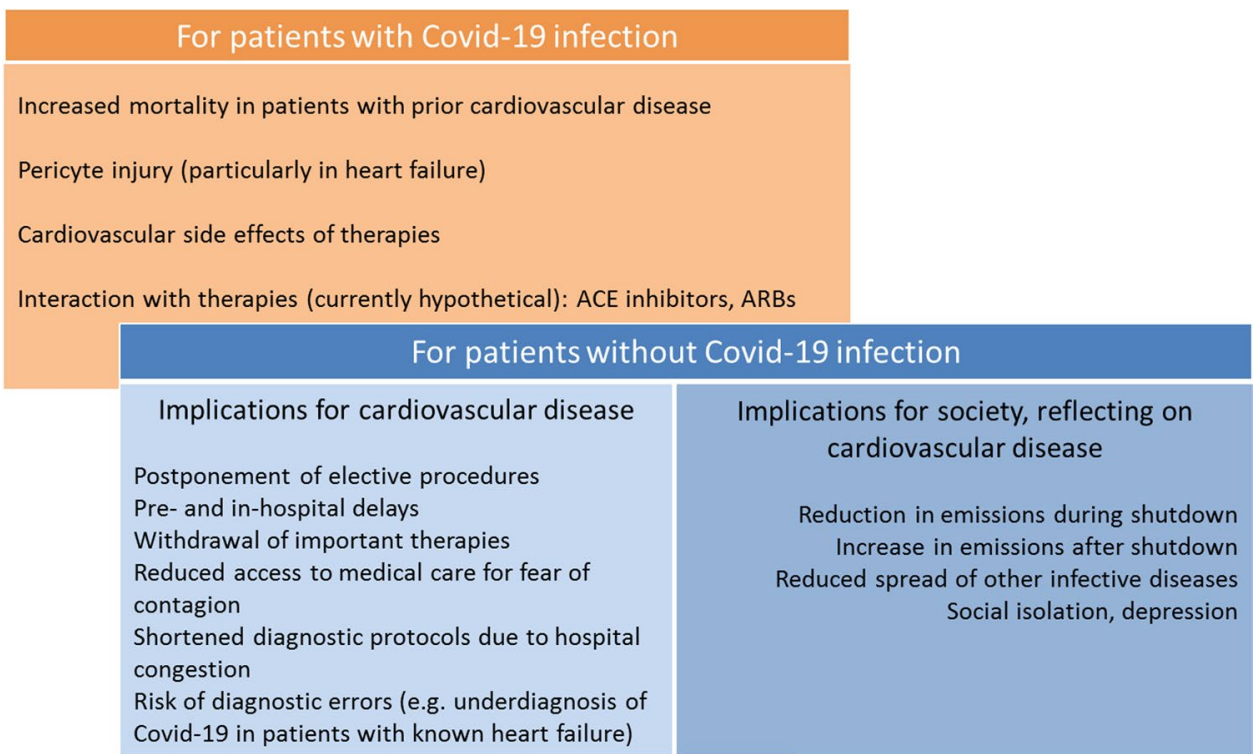

Covid-19 may initially be misclassified as heart failure or lung embolism, with catastrophic effects for the spread of the infection in cardiology wards or elderly houses. It is now of paramount importance that communication media inform the population that most large centers have restructured their admission protocols to provide a rapid and Covid-secure care of patients with acute coronary syndromes while still addressing the diagnosis of Sars-CoV-2 infection.

The impact of Covid-19 on cardiovascular mortality is, however, not limited to lack of resources in emergency 
regions. With the recognition of the ACE2 as the membrane receptor for SARS-Cov-2, it has been discussed whether angiotensin-converting enzyme inhibitors and angiotensinreceptor blockers represent additional risk factors for infection and mortality. While insufficient evidence is available up to this point [8], an uncontrolled spread of alarmistic "fake news" over social networks has caused major concerns in patients and physicians with regards to the possible implications of these important treatments for the prevention and treatment of stroke, hypertension and heart failure. Data on the number of patients who interrupted this type of therapy are yet unavailable, but the implications of withdrawal may become severe. International experts and the European Society of Cardiology "strongly recommend that physicians and patients should continue treatment with their usual anti-hypertensive therapy", given the lack of clinical or scientific evidence to suggest that treatment with angiotensin-converting enzyme inhibitors or angiotensinreceptor blockers might favor the spread or the severity of Sars-CoV-2 infection [9].

\section{Consequences of the society lockdown}

As a potential positive aftermath of the downturn of traffic and businesses, concentrations of some pollutants plummeted by as much as one half in industrial regions as traffic and manufacturing were arrested to slow the spread of SarsCov-2. Although the levels of other pollutants deriving for instance from domestic heating are not expected to drop, this observation might have indirect, positive health effects. Air pollution is known to be one of the main global health risks, which reduces the mean life expectancy by 2.9 years, more than tobacco smoking, HIV/AIDS and all forms of violence, including wars, together [10]. It causes as many as 8.9 million premature deaths per year worldwide [11], particularly through its impact on cardiovascular diseases.

Traffic-associated noise is another major risk factor for cardiovascular disease [12]. By the calculation of Burke [13], the suspension of all economic activities and traffic in China and the consequent decrease of environmental stressors might have reduced premature mortality in children and elderly citizens in more than 70,000 cases. If these estimates prove to be realistic, the indirect beneficial effects of the societal shutdown could possibly exceed the direct Covid-19 death toll. Following the start of the pandemic, however, the use of disposable plastic became a necessary hygienic measure to limit the spread of the virus. In 2019 and 2020, the European new green deal, including reduction of emissions to mitigate climate change, was at the top of the international agenda. In the near future, there is a risk that societies will accept "whatever it takes" to boost economies and return to "normal" life. Czech Republic's Prime Minister Andrej Babiš and Ungarian governmental spokespersons have already proposed that the resources planned for the European Environmental Plan should rather be used to support economy. It would be unwise, with major health consequences, when the steps undertaken to address air pollution and climate change were to be delayed or reversed.

Further to the implications of the shutdown, mortality from other infectious diseases will also be reduced as a cobenefit of the limitations to social contacts. There are, however, also negative implications to it. Altered socioeconomic status (unemployment), household stress, anxiety, depression, and the deprivation of social contacts have already been reported [14], and they are also major risk factors for cardiovascular disease, particularly in the elderly. The lack of financial support and of social integration are associated with hazard ratios in the range of 1.3-1.5 for cardiovascular and overall mortality [15]. Importantly, research suggests that loneliness, rather than social isolation (i.e. the perceived quality of social contacts rather than their number) is associated with increased risks of ischemic heart disease and stroke [15]. The solidarity shown by many individuals and organizations while facing this crisis must be supported with all possible means by governments.

In sum, the virus and its consequences directly and indirectly affect all aspects of our lives, with implications that are likely to last several months or even longer, possibly in a subtle way. First, there are immediate health implications (for infected persons as well as those with inadequate access to medical care). Second, the short- and long-term hazards, even for those not infected, need to be considered.

The Covid-19 crisis is a challenge to our society and health care systems. The solidarity that people and professionals have shown is moving and unprecedented. There are both risks and opportunities that this crisis might lead to a rethinking of priorities. Climate change may be more subtle as it does not progress as acutely as Covid-19, but needs equally strong action with the same solidarity and boldness. We have to decide now in which type of world we will live after this is over: in all its tragedy and with all respect for those affected, we should see the current situation as a stress-test for multiple trials ahead. Failure to respond, i.e. the paralysis or even reversal of environmental and climate policies, would be the worst alternative.

\section{Compliance with ethical standards}

Conflict of interest The authors have no conflicts of interest to declare. TM and TG are principal investigators of the DZHK.

\section{References}

1. Inciardi RM, Lupi L, Zaccone G, Italia L, Raffo M, Tomasoni D, Cani DS, Cerini M, Farina D, Gavazzi E, Maroldi R, Adamo M, Ammirati E, Sinagra G, Lombardi CM, Metra M (2020) 
Cardiac involvement in a patient with coronavirus disease 2019 (COVID-19). JAMA Cardiol. https://doi.org/10.1001/jamacardio .2020 .1096

2. Chen LL, Chen M, Feng Y, Xiong C (2020) The ACE2 expression in human heart indicates new potential mechanism of heart injury among patients infected with SARS-CoV-2. Cardiovasc Res. https ://doi.org/10.1093/cvr/cvaa078

3. Stefanini GG, Azzolini E, Condorelli G (2020) Critical organizational issues for cardiologists in the COVID-19 outbreak: a frontline experience from Milan, Italy. Circulation. https://doi. org/10.1161/CIRCULATIONAHA.120.047070

4. Villano A, Lanza GA, Crea F (2018) Microvascular angina: prevalence, pathophysiology and therapy. J Cardiovasc Med (Hagerstown) 19(Suppl 1):e36-e39. https://doi.org/10.2459/JCM.00000 00000000638

5. Naderi S (2018) Microvascular coronary dysfunction-an overview. Curr Atheroscler Rep 20:7. https://doi.org/10.1007/s1188 3-018-0710-5

6. Munzel T, Heusch G (2017) Chest Pain Unit Network in Germany: its effect on patients with acute coronary syndromes. J Am Coll Cardiol 69:2459-2460. https://doi.org/10.1016/j.jacc.2017.03.562

7. Tam CF, Cheung KS, Lam S, Wong A, Yung A, Sze M, Lam YM, Chan C, Tsang TC, Tsui M, Tse HF, Siu CW, Impact of Coronavirus Disease 2019 (COVID-19) (2020) Outbreak on ST-segment-elevation myocardial infarction care in Hong Kong, China. Circ Cardiovasc Qual Outcomes. https://doi.org/10.1161/ CIRCOUTCOMES.120.006631

8. Kuster GM, Pfister O, Burkard T, Zhou Q, Twerenbold R, Haaf P, Widmer AF, Osswald S (2020) SARS-CoV2: should inhibitors of the renin-angiotensin system be withdrawn in patients with COVID-19? Eur Heart J. https://doi.org/10.1093/eurheartj/ehaa2 35
9. Vaduganathan M, Vardeny O, Michel T, McMurray JJV, Pfeffer MA, Solomon SD (2020) Renin-angiotensin-aldosterone system inhibitors in patients with Covid-19. N Engl J Med. https://doi. org/10.1056/NEJMsr2005760

10. Lelieveld J, Pozzer A, Poschl U, Fnais M, Haines A, Munzel T (2020) Loss of life expectancy from air pollution compared to other risk factors: a worldwide perspective. Cardiovasc Res. https ://doi.org/10.1093/cvr/cvaa025

11. Lelieveld J, Klingmuller K, Pozzer A, Poschl U, Fnais M, Daiber A, Munzel T (2019) Cardiovascular disease burden from ambient air pollution in Europe reassessed using novel hazard ratio functions. Eur Heart J 40:1590-1596. https://doi.org/10.1093/eurhe artj/ehz135

12. Munzel T, Schmidt FP, Steven S, Herzog J, Daiber A, Sorensen M (2018) Environmental noise and the cardiovascular system. J Am Coll Cardiol 71:688-697. https://doi.org/10.1093/eurheartj/ ehy333

13. Panza JA, Laurienzo JM, Curiel RV, Unger EF, Quyyumi AA, Dilsizian V, Cannon RO 3rd (1997) Investigation of the mechanism of chest pain in patients with angiographically normal coronary arteries using transesophageal dobutamine stress echocardiography. J Am Coll Cardiol 29:293-301. https://doi.org/10.1016/s0735 -1097(96)00481-0

14. Lima CKT, Carvalho PMM, Lima I, Nunes J, Saraiva JS, de Souza RI, da Silva CGL, Neto MLR (2020) The emotional impact of Coronavirus 2019-nCoV (new Coronavirus disease). Psychiatry Res. 287:112915. https://doi.org/10.1016/j.psychres.2020.11291 5

15. Valtorta NK, Kanaan M, Gilbody S, Hanratty B (2018) Loneliness, social isolation and risk of cardiovascular disease in the english longitudinal study of ageing. Eur J Prev Cardiol 25:13871396. https://doi.org/10.1177/2047487318793456 